\title{
FROM STONE GRAVES TO CHURCHYARDS. BURIAL TRADITIONS IN THE LATE PREHISTORIC AND EARLY MEDIEVAL ISLAND OF SAAREMAA
}

\author{
Marika Mägi
}

\begin{abstract}
Even though pre-historic burials have been the favourite topic of research of Estonian archaeologists at least for the past century, the focus has been on their appearance, chronology, ethnic context and objects discovered in them. Burial tradition, as it reflects in the archaeological remnants, has hardly been studied.

Research in the field over the past few years, as well as osteological analysis of bone material, which was first carried out in the $1990 \mathrm{~s}$, has introduced new findings in the funeral customs of our ancestors.

The article examines funeral customs on the island of Saaremaa, and the ideology behind it. The main focus is on the final centuries of the prehistoric period and the beginning of the Middle Ages - more specifically, on changes brought along by Christianity, although the study also provides an overview of earlier customs. A separate chapter discusses the partial distribution of bones and objects in graves, objects determining the boundaries of graves, and traces of funeral rituals. This evidently reflects a set of traditions, and thus also conceptions about the otherworld, composed of multiple layers and differing considerably from the modern funeral tradition. Christianisation of the population of Saaremaa in the 13 th century changed these conceptions beyond recognition over a very short period of time.
\end{abstract}

Keywords: burial customs, Christianisation, rituals, Late Iron Age, Middle Ages, Saaremaa

Burial tradition is one of the most conservative ideological conceptions in a society. Changes in burial customs are preconditioned by critical changes in religious thought, and usually happen over a longer period of time, often over centuries. What we know about burials is based on Christian practices and seems to apply to the paganistic times. Knowledge about cremation burials and placing grave goods for afterlife more or less fits the same framework. Thousands of years ago, however, concepts about proper burial were altogether different from what they are now. Several traditional tribes 
in distant places of the world, like Africa or Indonesia, still practise highly unusual funeral rituals.

Prehistoric graves excavated on the island of Saaremaa to this date have been predominantly multiple burials for one family, less frequently for two, suggesting that the graves that have not been excavated are also mostly family burial sites. According to demographic estimations on grave material from Estonia, there is no doubt that the known prehistoric stone graves were used for burial only by a part of the society, most likely the local elite throughout prehistoric times (Lang \& Ligi 1991; Mägi 2002: 74). Others, a considerably larger part of the population, buried their dead in another way, which remains invisible to modern archaeology. Dead bodies may have been left to wild animals and birds, or cremated, the ashes thrown in the wind or into some waterbody. Therefore, the following treatment of stone graves in Saaremaa and burial traditions related to them concerns only the contemporary elite, namely, wealthier land-owners and their families. Henry of Latvia has called them seniores, meliores, or on one occasion also nobiles in his chronicles (see Mägi 2002: 138 ff).

As suggested by ethno-archaeological parallels in traditional societies up to the present time, it is quite common that in the more complex multiple-stage burial tradition the complete ritual was a prerogative of the elite. The majority of the population, people of lower social rank, were buried in a simpler way and had no grandiose burial monuments. Somehow the situation caused no ideological conflicts (Metcalf \& Huntington 1999: 101, $135 \mathrm{ff}$ ).

The present article discusses the burial tradition of Saaremaa and its gradual Christianisation in the last stages of the prehistoric period - the Viking Age (800-1050 AD) and Late Iron Age (1050-1200/ $27 \mathrm{AD}$ ) in more detail. In order to explicate the ideological views of the people of Saaremaa, I have also pointed out some characteristic features of the earlier periods of prehistory, Roman and Pre-Roman Iron Age, to the extent allowed by the scanty archaeological data. 


\section{GRAVE TYPES ON THE ISLANDS OF SAAREMAA AND MUHU: A BRIEF OVERVIEW}

The first stone graves in Saaremaa date back to the Bronze Age, though a larger number of stone graves were constructed in PreRoman Iron Age. The number of grave goods increases towards the beginning of the recorded time. The same period witnesses the emergence of cist graves with irregular small rectangular enclosures (tarand in Estonian), and earlier stone circle graves. The latter lacked a chest or a casket and the stone circle was smaller in diameter than that of cist graves.

It is debatable where the ancient people of Saaremaa buried their dead in the 2nd-3rd century $\mathrm{AD}$, but it is speculated that they continued to use the old stone graves. However, the latest research has dated tarand graves with regular construction to the 2 nd-3rd, as well as the 4 th-5th centuries. Tarands consist of several adjacent enclosures surrounded by a limestone wall with granite basement (Mägi-Lõugas 1996; 1997).

Of the 7 th -9 th century graves archaeologists have discovered stone circle graves in Mäla, the island of Muhu (Holzmayer 1880: 25-31). More stone circle graves were constructed in the 10 th -11 th century. These were round graves surrounded by a stone wall, usually $2.5-4.5 \mathrm{~m}$ in diameter. Some stone circle graves had no wall and the circle of larger granite rocks was filled with stones the size of a human head, forming a mound on the grave. In the western part of the island cairns have been found. Cairns have no stone circles and the burial is simply covered with a pile of stones (see e.g. Kustin 1966).

In some areas stone circle graves and cairns constituted burial grounds of dozens of graves, where the area between the graves was sometimes paved with limestone slabs. Almost all the graves contained cremated remains of a single body. Some burials were located between stone circle graves and were simply covered with a stone layer (Mägi et al 1997; Mägi \& Rudi 1999; Mägi 2002: 125128).

From the 11th century onward the people of Saaremaa began to bury their dead in graves without internal stone constructions. 
Burials were usually covered with several layers of stones, forming an imposing view with the large granite rocks in the vicinity. Most burials were still distinguishable under the stone layer. The burial tradition of graves without inner constructions bore resemblance to that of stone circle graves and barrow mounds, though the grave goods were usually much more lavish. The only noteworthy distinction for archaeological research was that the remains of funeral pyres were simply covered by one or two layers of stones, and no stone circle was constructed on the remains (Mägi 2002: 128-129).

In western Saaremaa inhumations began towards the very end of the 12 th century. Most inhumations on the islands of Saaremaa and Muhu, however, date back to the period following Christianisation, which eradicated cremation burials.

\section{BURIAL TRADITIONS BEFORE THE VIKING PERIOD}

Even though the grave types characteristic of the first half and the middle of the Iron Age were determined a long time ago, recent years have seen considerable changes in conceptions about the burials of Saaremaa and speculated burial customs related to these. The 1995-2000 excavations of Tõnija Pre-Roman and Roman Iron Age tarand graves, in the course of which the bone material of the site was analysed, are of great significance in this aspect.

Osteological analysis revealed that although the dead bodies were inhumed, none of the skeletons in the graves was intact. The graves contained incomplete skeletons, with bones mostly crushed to pieces. Some bones displayed obvious effects of long-term weathering before interment. Only few of the bones, mostly pieces of skulls, were cremated, whereas the burning marks indicated that the bones had been cremated, not the body (Mägi-Lõugas 1996; 1997; Mägi 1999). Analogous results were obtained in the osteological analysis of bone material from several cist and tarand graves in North Estonia (e.g. Kalman 2000a; 2000b; Lang \& Kalman 2000), and from earlier excavation reports of the Bronze Age and Early Iron Age graves in Saaremaa. Osteological materials therefore suggest the practice of secondary burial, which is still widely followed among the primitive tribes of the world. According to this practice the first stage of the burial was separating the bones, either through first 
interment for a period of time, excarnation of bones, boiling, or some other way. The secondary burial ritual was taking the bones to the final burial site (see e.g. Metcalf \& Huntington 1999: $85 \mathrm{ff}$ ).

Less is known about the funerary practices of the 7th-9th century due to the scarcity of graves of this period. Some secondary burials from the Pre-Viking or Early Viking period, discovered in earlier stone graves, contain bones cremated elsewhere and brought to the grave with single burned fragments of objects (e.g. Kustin 1963; Mägi-Lõugas 1997). Apparently it was important to emphasise continuity and ancestral ties rather than the status of an individual.

\section{TH-12TH CENTURY STONE BURIALS AND BURIAL PRACTICES}

Cremation burial tradition is generally associated with the belief that only the complete destruction of the physical body enables the soul to pass on to the supernatural ancestral world. This bears affinity to the ancient Finno-Ugric belief according to which a human has many different souls of which at least one may join the other world, but only through complete destruction or transformation of the body (Pentikäinen 1990: 21-24; Purhonen 1998: 40). Scholars have speculated on a possible sun cult, where burning pyre may have symbolised the life-giving force of the Sun, as well as on the ideological need to destroy the body in order to prevent it from returning to the living. The idea of freeing the soul through burning is associated with the concept of "dual" death, i.e. a person was not considered completely dead before its body was destroyed. Anders Kaliff has argued that such beliefs survived in church practices to burn witches and other criminals on pyres - by executing them completely, they were deprived of eternal life (Kaliff 1992: $61 \mathrm{ff}$ ).

An important aspect of burials of persons high up the social hierarchy was the transition period in the secondary burial ritual. The period when the chief or leader was not "completely" dead was a time for taking over the political power by his successor, who ascended the leading position only after the secondary ritual (Metcalf \& Huntington 1991: $135 \mathrm{ff}$ ), which in the cremated burials of Saaremaa was probably the interment of bones. Although the stone graves of Saaremaa belonged to wealthier families with higher so- 
cial status, the graves were used for burying all the members of the family. It is likely that social status determined not only grave goods and/or the size of individual grave monuments, but also the length and nature of burial rituals, which do not reflect in archaeological material.

Parallels with cremation burials and sun cult hardly apply to the burials of Saaremaa. Even though the ethnographic material of the Baltic area dates back to a considerably later period and has been strongly influenced by Christian practices, the worship of sun was clearly a part of the mythological worldview of the Baltic tribes. In Estonian and Finnish folklore the Sun is rarely mentioned, and even then the attitude towards it is hardly glorifying. Regardless of that, the Baltic tribes, at least in Latvia, practiced mostly inhumation in the Late Iron Age, whereas in Estonia cremations were more common.

Only seven of the 10th-12th century stone burials of Saaremaa have been excavated by means of modern methods. The following results largely rely on the 1997-1998 excavations of the Piila stone circle cemetery, which has prompted new analyses of earlier excavation reports of burial sites, such as the excavation of the stone circle graves of the Käku cemetery conducted in 1948-49 (Metsar 1949 ; 1959) and excavations of the Rahu stone burial during 19591963 and in 1980 (Kustin 1969a; 1969b; 1970a; 1970b; 1970c; Lang 1980).

\section{(a) Cremation on funeral pyre}

The culmination of the burial rituals has always been known to be the cremating process, while collecting the remains from the pyre and their interment was ideologically of secondary importance (Kaliff 1992: $68 \mathrm{ff})$. It is likely that the interment of remains into stone grave, its construction or use demonstrated first and foremost social prestige, whereas the cremating process bore mostly religious significance.

No specific places for burning the dead are registered in Saaremaa, though the descriptions of some 19th century sites may suggest of some. Analogous material of the neighbouring regions reveal that bodies may have been cremated on the site of the later burial, on 
the outskirts of a cemetery or the highest point of a cemetery, in some cases also at a different location altogether (Gräslund 1978; Kaliff 1992: 129-130).

The dead body was placed on the funeral pyre together with grave goods. According to modern archaeological understanding, grave goods reflect the ritual conceptions of the given society, being closely interrelated with the social and political structure of the society. The richness or poorness of graves is, however, not directly related to the economical situation of the society, but rather to the dominant ideology in this society. Each object placed in the grave was ritu-

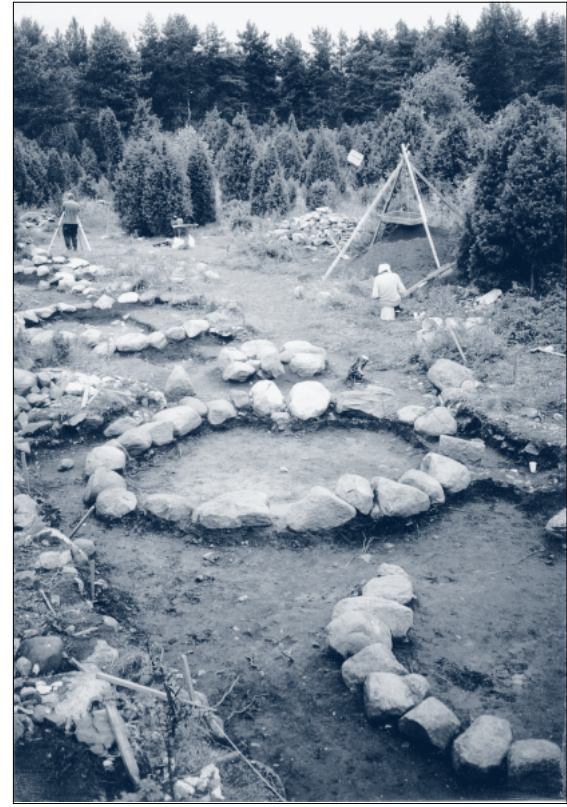

Photo 1. Cleared stone circles from the Viking period at the cemetery of Piila. Photo by author.

ally significant, and therefore closely related to social manifestation (Hodder 1982: 119-122).

Most of the grave goods at cremation burial were deliberately destroyed or ruined before they were placed on the pyre. Analogous practices have been discovered in stone burials in Finland and Sweden (Kaliff 1992; Karvonen 1998). The intentional ruining of the grave goods is usually explained by releasing their "spirit" to the otherworld, the fear for revenants, or the belief that our world is mirrored in the other world, where everything is the other way around (Karvonen 1998: 5; and references to the article). Other possible, though less likely, explanations are the practical ones, such as the need to ruin weapons because of grave robbers, or to limit the amount of cremation remains to fit into containers of special size.

Iron nails and rivets found in cremation graves suggest that the dead body may have been placed on the funeral pyre on a support or 
in a casket. The small number of nails in inhumations rather seems to refer to their symbolic function, since caskets were mostly built with wooden pegs. Here it is possible to draw parallels with the practice described by Finnish archaeologist Nils Cleve, according to whom the lid was nailed to the casket or a nail was driven to the casket, especially to the head of the casket, during the burial ceremony. Cleve argues that this served as a protective method against the dead and is associated with the practise of "sealing" the casket with a sharp tool (Cleve 1978: 86-89; and references to his article). As to nailing the casket, analogous beliefs were also known in Estonia. Sometimes a nail was driven to the threshold sill after the deceased was carried out of the house (Lang 1981: 52-53, 67; Viluoja 2000).

Single iron rivets discovered on burial sites may have also been driven in a box or casket which was laid on the pyre with the deceased and was, analogously to pottery, crushed during grave constructing ritual (Cleve 1978: 86-89; and references to the article). According to Anne-Sofie Gräslund, rivets found in the Birka inhumation grave in Sweden might suggest that the deceased may have been buried in a treasure chest, carriage or sledge (Gräslund 1980: $15 \mathrm{ff}$ and references to the article). The same may have applied to cremations, although these objects may also have been placed to the pyre as grave goods.

\section{(b) Interment of bones into stone graves}

Following the incineration and cooling down of the pyre, the burned bones and smaller fragments of goods were placed in pottery urns, while larger items (weapons, bridle, scythes, etc.) were placed in the graves separately. At richer burials with more grave goods, the remains gathered from the pyre may have been placed in several pottery urns. Pottery and its contents were crushed at the later burial site, most probably thrown to the ground.

The thin layer of coal under the Piila stone burial and elsewhere in Saaremaa indicates that fire was made at the grave: very likely with the purpose to purify the grave through ritual fire. As suggested by frequent discoveries of coal layer, pottery shards and grave goods under stone circle graves, a stone grave was usually con- 
structed only after crushing the pottery. Larger items, like weapons and tools, were often placed under circle stones (e.g. Metsar 1949; Kustin 1966: 89).

The bone material of cremation burials discovered in Saaremaa is heavily calcified and in small fragments. At Piila cemetery, where bones were osteologically analysed, the weight of human bones in one burial ranged from $3.2 \mathrm{~g}$ to185.5 g (Mägi et al 1997: Table 1). Similar fluctuation has been noticed with burials in Sweden (Sigvallius 1994: 28-32). Kaliff associated the small amount of cremated bones in stone graves with the conception that partial skeleton was considered enough to represent a deceased in the grave, or that in some regions the remains of the deceased were distributed between different graves (Kaliff 1992: 121-122). Both in Sweden and in Saaremaa people followed an ancient practice of interring only a part of the skeleton to the stone grave, as this type of burial was common already in the Bronze Age.

The ritual crushing of cremated bones appears to be analogous to the intentional destruction of grave goods before placing them on the funeral pyre. In both cases the "death" was dual, guaranteeing the complete freeing of the spirits of the deceased and the items. Perhaps another reason why not all bone splinters were gathered from the pyre is that the culmination of the burial ritual was the burning process. If so, then at some point people may have considered necessary to place grave goods to the pyre, but not inter them after incineration (Kaliff 1992: $68 \mathrm{ff} ; 103,107,121$ ). It is likely that the cremations in Saaremaa manifested similar beliefs. It often appears that the intent was to bring only a part of each object that was burned at the pyre to the grave, possibly those of greater symbolic significance.

\section{(c) Grave goods serving as markers and/or protective measures}

Around burials in stone graves without internal constructions, spearheads, throwing-spear heads, knives and other sharp objects have often been found in the area between graves, separately from cremated bones and other objects. Here, clear parallels can be drawn with stone circle graves, where weapons, scythes, bridle and knives 
have been found under circle stones. While some of them had been placed there during the construction of the grave, two knives discovered in the stone mound above the stone wall of Grave 5 in Piila had clearly been placed there after the grave was completed (Mägi \& Rudi 1999: 42-43).

The function of the sharp instruments found in the outskirts of the burial ground may have been to protect the living against the dead, or the dead against evil forces. Even in later periods, in Southeast Estonia it was customary to place a knife to the grave of an unbaptised child, to protect the child against devil (Valk 1999: 82). It is also possible that the knives, spearheads, axes and other sharp objects were placed under grave stones to avoid the return of the deceased. Evidently, in an inhumation grave at Luistari cemetery in Finland a knife had been placed on the throat of a female corpse for this very purpose (Lehtosalo-Hilander 1982: 21). Spearheads found at a site with no other findings must have marked the boundaries of graves. Often these objects were not burned and have been found poked aslant between the stones, indicating that originally the spearheads jabbed there also had a shaft (e.g. Indreko 1940: 7).

Accounts of the use of spearheads and other iron objects as markers of graves or burials are known elsewhere. In Finland the caskets of paganistic inhumations were sometimes "sealed" with spearheads. Cleve argues that spearheads must have functioned as protection against the deceased (Cleve 1978: 86-89 and references to the article; see also Purhonen 1998: 165). In chamber graves of the Viking period in Birka, Central Sweden, spearheads were sometimes prodded into the walls of grave chambers or into burial platforms. The same occurred at cremations in Birka, where spearheads, axes, daggers and once even a part of a vertically placed sword have been found, and also in some cremation graves of the Viking period in Gotland and at the Järvafälte cemetery in Central Sweden (Gräslund 1980: 76 and references to the article).

\section{(d) Postburial rituals and sacrifice on graves}

All the stone graves in Saaremaa contain uncremated or slightly burned animal bones, and the large number of potsherds, sometimes clearly distinguishable in upper layers, suggest of performed 
rituals or ritual meals after burials. The ritual custom of commemorating the dead with a meal at the cemetery is still practiced in the Setu County, Southeast Estonia (Valk 1999: 82-84).

Postburial rituals are also associated with the custom of placing coins and items of jewellery to the graves. Objects originating in considerably later period than the graves have been discovered in many Estonian stone graves; the practice survived even in Christian village cemeteries. The best example of grave goods of the more recent period in the graves in Saaremaa was a pendant made from a 13th century coin, found in a grave in Rahu. The grave dated to the first half of the 11th century at the latest, and had no longer been in use at the time the coin was stamped (Mägi 2002: 110).

\section{BURIAL PRACTICES IN EARLY CHRISTIAN PERIOD}

Although several reports from Saaremaa indicate that inhumations were performed even earlier, the first reported inhumations in Saaremaa could be dated to the very end of the 12th century. In Southwest Finland and Central Sweden, which in the Viking period belonged to the same culture area together with the island of Saaremaa, the transition to Christian burial practices had taken place already in the 11th century; by the year 1200 paganistic burial tradition must have been completely abandoned by the locals. In Saaremaa, however, cremation had been the only type of burial since the 7th century, and before that people of Saaremaa had practised burial where only a part of the uncremated or sometimes also cremated skeletons were interred into a stone grave (see discussion above). In the 12 th -13 th century simple pit burial must have been a completely untraditional burial type for the people of Saaremaa, even though they definitely had close contacts with their neighbours.

The idea of freeing the spirit through a complete destruction of the physical body, which had been fixed in the mental conceptions of the people of Saaremaa over at least two centuries, transformed to the complete opposite over less than a generation in the first half of the 13 th century. An even greater change in the religious worldview of people and in ideology legitimising social and political order, brought along a transition from the burial of two or more stages 
(cremation, crushing of bones, interment into stone grave) to primarily one-stage burials (inhumation into pit grave). The longer burial ritual consisting of several different transitional stages, together with conceptions of the need to destroy grave goods "to death", the representation of the deceased with only partial skeleton, and the representation of grave goods with fragments of objects, etc. was replaced with an altogether different view of the otherworld. According to the Christian doctrine a burial was followed by waiting for Judgment Day, resurrection and only then the eternal existence in Paradise or Hell. Thus the transition rite was shifted in the minds of people to the period following the burial.

Examples of the interrelation of these two conceptions in the transition from one burial tradition to another are known in areas neighbouring Saaremaa. These conceptions were both associated with fire, which appeared to play an important role in earlier inhumations. Scholars have observed that at the 12th century inhumations in mainland Estonia, fire has been made in a grave. In a child grave at Kaberla cemetery two sooted slabs of limestone, discovered under the skeleton, point to cremation. At Küti cemetery the caskets in two female graves were strongly burned, suggesting that a fire was made on the lid after interment (Selirand 1962: 139). At Hovinsaari cemetery in Karelia a 12th century female body was found half-burned: the upper half of the body had been burned, while the lower half remained unburned. Interestingly, grave goods had been placed as if the skeleton had been completely uncremated (Kochkurkina 1982: 42).

We may assume that most paganistic remnants in burial traditions are not archaeologically detectable. Astonishingly, there are many traces of it in ethnographic material, mostly from areas east of the island of Saaremaa where transition to Christian burial practices happened over a longer period of time. I have already mentioned the customs of placing grave goods in the graves and taking ritual meals on graves. Single reports have also suggested the use of fire in burial rituals. Even in the 18th century the Balto-Finnic people living in Northwest Russia and the Estonians still practised the ritual carrying of the casket over fire at funerals. In this way the straw on which the person had died were burned (Öpik 1970: 113, $115,160)$. 
The general criteria for determining a burial as Christian are orientation of head towards the west, no grave goods and burial into consecratedground. The head of the body had to be oriented towards the west, facing the east, where Christ was believed to appear on doomsday. This custom was fixed in Christian burial practices already in the 3rd century (Gräslund 1994; Purhonen 1998: 119). There are, of course, deviations from the rule, especially in newly Christianised areas. Burials oriented to different directions are known in otherwise Christian cemeteries in Finland dating back to the period of crusades (Purhonen 1998: $121 \mathrm{ff}$ ); the same is known to apply to Saaremaa.

In terms of grave goods, Christian ideology excluded all larger objects, such as weapons, food, animals, tools, etc., while jewellery attached to clothing and other attributes survived for a certain period of time after Christianisation almost everywhere. In Sweden and Finland, grave objects were abandoned in Christian burials within 50-100 years. The abandonment of grave goods is associated with postburial conceptions and beliefs in eternal life, which were highly different from the paganistic worldview. Some exceptions to the rule - burials with grave goods, mostly those of people of high social status - still occurred in the Christianised countries of Western and Central Europe up to the 16th century (Staecker 1999: 318333). In the Baltic area and in Northwest Russia grave goods were commonly, and even recently, placed to the graves of peasants.

\section{(a) Inhumation outside churchyards}

The earliest inhumations in Saaremaa are known from Loona, Kihelkonna parish, in the late 12th or early 13th century. During 1956-1958 seven skeletons with grave goods were excavated from the burial site. Most of the skeletons were female, oriented with head towards the north, which was characteristic of the Balto-Finnic tribes before Christianisation (Kustin 1959; Mägi 2002: 63-65). These burials were still utterly paganistic in nature, analogous to what was practiced in North Courland, by the Livonians and the Votes. The Loona burials are therefore not so much manifestations of the influence of Christianity, but rather adaptations to inhumation practices that had already become prevalent in the neighbouring areas of Saaremaa in the 12th century. Whether and how this introduced 
changes in burial practices and sepulchral conceptions is impossible to determine on the basis of the scanty material.

Two archaeologically excavated inhumation cemeteries - Pärsama in Karja and Viira on the island of Muhu - were more Christian in nature. All graves at these cemeteries were oriented with head at the west, southwest or northwest, clearly following the Christian tradition. At the cemeteries, especially in Viira, grave goods were particularly modest, consisting mostly of items of jewellery, knives or belts (Kustin 1958; 1964; Mägi 2002: 66-74).

In terms of grave goods the cemetery of Karja appeared more paganistic in nature than Viira. Some metal objects that were not directly attached to clothing were clearly placed in the graves of the dead as grave goods. For example, a penannular brooch and a knife were discovered in a grave of a child, and a ring was found next to a female skeleton's shinbone. In several graves a belt buckle was found in unusual places, mostly near skeleton's legs - probably from the remains of a belt coiled together at the foot. Knives that were not attached to belts were noticed in several burials at the Karja cemetery; knives were often placed between the knees with a blade pointing towards the skull or under the skeleton's back. At female graves the casket was sometimes covered with a plaid with bronze spiral ornamentation. A female buried at the Karja cemetery with foetal bones in the pelvis area had a knife placed on her chest. Possibly, the knife served as protection for the unborn and therefore unbaptised child (see also Valk 1999: 82). A string of beads with a coin pendant, discovered on the pelvic bones of the same skeleton, may have been intended as the grave good for the child.

Paula Purhonen has argued that some cemeteries in Finland, which dated back to the period of crusades, may have surrounded a chapel. According to her, the land must have been consecrated (Purhonen 1998: 123-129). In great likelihood the same can be assumed of the cemeteries in Saaremaa, especially since the 17th century church visitations contain complaints about the peasant practices to bury their dead around ancient chapels (Kõpp 1959: 258, 282-284). Excavations at the Karja and Viira cemeteries revealed that more people have been buried there than just a single family, thus suggesting that these had been the burial grounds of a part of the congregation. Judging by the total number of skeletons and the fact that 
all skeletons with datable grave goods were dated to the 13 th century, it appears that neither of the cemeteries was used over a longer period of time. It is likely that the last burials were made to these cemeteries in the 14th century.

\section{(b) Inhumations with grave goods inside churchyards}

The grounds around churches and chapels were consecrated, and burying there definitely followed Christian norms. A baptised Christian had a right to be buried in the consecrated ground, where no unbaptised person was allowed. The burial of unbaptised people, suicide victims, people who had violated church peace and other Christian practices on consecrated ground would have desecrated it, and were therefore carefully avoided (Purhonen 1998, 119-120). Some newly Christianised areas, though, allowed exceptions, such as the article in a 1255 contract with the people of Saaremaa stating that suicide victims would not be punished there (see Mägi 2002: 36). Apparently, on such occasions the old common law was preferred instead of the Christian. Quite likely, cancelling punishment meant being granted the right to be buried in the consecrated ground.

In the churchyards of Gotland and in some parts of mainland Sweden some grave goods, mostly jewellery, have been found next to skeletons. Most burials with grave goods belonged to women. This is because in the 11th-12th century pre-Christian Northern Europe it was customary to bury women north of the church, while men were buried south of the church. When in the 13th century a belief according to which churches were believed to fall to ruins towards the north, thereby rendering the resurrection of those buried there impossible, began to circulate, the deceased were no longer buried north of the churches. This explains why the 11th-12th century female graves in the churchyards of Northern Europe are in better condition. For a long period of time the northern side of churchyards was used for burying the marginal members of the society, including, for example, suicide victims and criminals (ThunmarkNylén 1991; Purhonen 1998: 128; Staecker 1999: 312).

Three graves with grave goods have been excavated at the Valjala churchyard in Saaremaa - two female bodies buried south of the 
church, and a male skeleton buried north of the church. Jewellery and parts of clothing that may refer to burials with grave goods have also been found near the church of Valjala, in the churchyards of Muhu, Kaarma, Kihelkonna, and Mustjala (around the chapel that was believed to be there in the 13th-14th century). Numerous grave objects have also been found elsewhere in Estonia; some burials with grave goods have been discovered next to the Viru-Nigula church (Tamla 1991; 1992).

We may assume that in the 13 th century the dead were buried with jewellery and other grave goods around and perhaps also inside of all the churches in Saaremaa. The presence or richness of jewellery may have emphasised higher social status, but could also refer to the religious convictions of the deceased and/or his or her family. According to the Christian attitude the social position of the deceased could be determined first and foremost by the position of the grave, its distance from the altar or the church (Staecker 2001; Valk 1999: 17-18). The high social status of two female burials in Valjala, for example, is indicated by grave goods as well as the location of the grave right next to the church wall.

In the 13th-14th century, therefore, the dead in Saaremaa were buried either in churchyards and perhaps in churches, or in chapels and the surrounding graveyards. Sometimes the dead were also buried in cemeteries further away from churchyards, which, as I have indicated above, were in great likelihood also considered consecrated ground. Thus we may assume that the people of Saaremaa had adopted the social aspect of Christian burial traditions, i.e. marking of social status with the location of burial. Even though no objects from the 13th-14th century have been found inside the churches of Saaremaa, it is logical to conclude that the elite, who in the 12 th century had been buried in large stone burials with lavish grave goods, were now buried directly next to church walls or inside the churches. This is evidenced, among other things, by gravestones with mixed Christian and paganistic symbols dated to the first half of the 13th century that have been discovered in the oldest churches on the islands of Saaremaa and Muhu (Pesti \& Rikas 1991: 72-76; Sipelgas 2000; Markus 2003; further on attitudes towards Christianity in Saaremaa see Mägi 2002: 150-157). 


\section{CONCLUSION}

Burial traditions in Saaremaa in the Viking Age and Late Iron Age clearly rooted in an earlier tradition of partial burial, as evidenced in the excavation of stone cist and tarand graves. The only difference from the previous tradition was transition to cremation. On a smaller scale, cremation was already known in the Bronze Age and in the first half of the Iron Age. Until the end of the paganistic period burial tradition was closely associated with the custom of interring only a part of bones to the family burial site. A certain ideological change appears to have happened in the Viking period, namely in terms of attitudes towards grave goods, which in the graves of the first half of the Iron Age have been found largely intact. Towards the end of the Iron Age people considered necessary to destroy the objects placed in graves, as well as the dead bodies. It is reasonable to assume that the principles of Christian burial tradition were well known long before the conquest and official Christianisation of the land, largely because their close contacts with neighbours - the already Christianised peoples. This influence is indirectly suggested by the late 12th century inhumations in western Saaremaa and by the common custom of placing less grave goods to the grave. The abrupt abandoning of cremation in the early 13 th century and the constant decrease in the amount of grave objects until their complete disappearance in the following century were clearly associated with the conversion to Christianity and adopting of the attitudes and values of Christianity by the people of Saaremaa.

\section{References}

\section{Manuscripts}

Indreko, Richard 1940. Aruanne noorema raua-aja kivikalmistu kaevamistest Pöide khk. Randvere kl. Matsi tl. maal 28.V-16.VI. 40. a. [Excavation report. Matsi farm, Randvere village, Pöide parish, May 28 June 16, 1940]. Manuscript in the Topographical Archives of the Department of Archaeology, Institute of History, Tallinn. 
Kustin, Aita 1963. Aruanne Liiva-Putla kalmumäe kaevamisest 1963. a. [Excavation report. Liiva-Putla burial mount in 1963]. Manuscript in the Topographical Archives of the Department of Archaeology, Institute of History, Tallinn.

Kustin, Aita 1964. Aruanne Muhu Viira laibakalmistu kaevamisest 1962. a. [Excavation report at inhumation cemetery in Viira, Muhu Island in 1962]. Manuscript in the Topographical Archives of the Department of Archaeology, Institute of History, Tallinn.

Kustin, Aita 1959. Aruanne Kihelkonna Loona maa-aluse laibakalmistu kaevamisest 1956.-1958. a. [Excavation report at the subterranean inhumation cemetery in Loona, Kihelkonna parish in 1956-1958]. Manuscript in the Topographical Archives of the Department of Archaeology, Institute of History, Tallinn.

Kustin, Aita 1969a. Aruanne Rahu kivikalme kaevamisest 1959. aasta [Excavation report at the Rahu stone burial site in 1959]. Manuscript in the Topographical Archives of the Department of Archaeology, Institute of History, Tallinn.

Kustin, Aita 1969b. Aruanne Valjala Rahu kivikalme kaevamisest 1960. aastal [Excavation report at the Rahu stone burial site in Valjala in 1960]. Manuscript in the Topographical Archives of the Department of Archaeology, Institute of History, Tallinn.

Kustin, Aita 1970a. Aruanne Valjala Rahu kivikalme kaevamisest 1961. aastal [Excavation report at the Rahu stone burial site in Valjala in 1961]. Manuscript in the Topographical Archives of the Department of Archaeology, Institute of History, Tallinn.

Kustin, Aita 1970b. Aruanne Valjala Rahu kivikalme kaevamisest 1962. aastal [Excavation report at the Rahu stone burial site in Valjala in 1962]. Manuscript in the Topographical Archives of the Department of Archaeology, Institute of History, Tallinn.

Kustin, Aita 1970c. Aruanne Valjala Rahu kivikalme kaevamisest 1963. aastal [Excavation report at the Rahu stone burial site in Valjala in 1963]. Manuscript in the Topographical Archives of the Department of Archaeology, Institute of History, Tallinn.

Lang, Valter 1980. Aruanne Rahu kivikalme kaevamisest 1980. aastal [Excavation report at the Rahu stone burial site in 1980]. Manuscript in the Topographical Archives of the Department of Archaeology, Institute of History, Tallinn.

Lang, Merike 1981. Endisaegsed matmiskombed Ida-Eestis [Past burial traditions in East Estonia]. Degree thesis. Manuscript in the archives of the Department of History, University of Tartu.

Metsar, Leo 1949. Aruanne Kaarma valla Käku küla Kilgiaugu paemurru põhjakaldal asuva kivikalme kaevamisest 13. VIII - 27. VIII 1948. a. [Excavation report at the stone burial site on the northern slope of Kilgiaugu limestone bank in Käku village, Kaarma parish. August 13 - August 27, 
1948]. Manuscript in the Topographical Archives of the Department of Archaeology, Institute of History, Tallinn.

Metsar, Leo 1950. Aruanne Kaarma valla Käku küla Kilgiaugu paemurru põhjakaldal asuva kivikalme kaevamisest 1.-29. VII 1949. a. [Excavation report at the stone burial site on the northern slope of Kilgiaugu limestone bank in Käku village, Kaarma parish. July 1 - July 29, 1949]. Manuscript in the Topographical Archives of the Department of Archaeology, Institute of History, Tallinn.

\section{Publications}

Cleve, Nils 1978. Skelettgravfälten på Kjuloholm i Kjulo II: Vikingatid och korstagstid [Humation burial grounds on the Köyliö Island, Köyliö 2: Vikingatid och korstågstid]. Gravfältet C: Suomen Muinaismuistoyhdistyksen Aikakauskirja = Finska Fornminnesföreningens Tidskrift 44: 2. Helsinki.

Gräslund, Anne-Sofie 1978. Bränning på platsen eller särskild bålplats?: Några notiser om ett bränningsförsök. Tor 17, pp. 363-373.

Gräslund, Anne-Sofie 1980. Birka 4: The Burial Customs: A study of the graves on Björkö. Stockholm: Almqvist \& Wiksell.

Gräslund, Anne-Sofie 1994. Graves as evidence of Christianisation. Stjernquist, Berta (ed.). Prehistoric Graves as a Source of Information: Symposium at Kastlösa, Öland, May 21-23, 1992. Konferenser 29. Uppsala: Kungl. Vitterhets, historie och antikvitets akademien, pp. 201-209.

Hodder, Ian R. 1982. Symbols in Action: Ethnoarchaeological studies of material culture. New Studies in Archaeology. Cambridge: Cambridge University Press.

Holzmayer, Jean Baptiste 1880. Osiliana III. Verhandlungen der gelehrten Estnischen Gesellschaft zu Dorpat, Bd. 10. Dorpat: [s.n].

Kaliff, Anders 1992. Brandgravskick och föreställningsvärld: En religionsarkeologisk diskussion. Occasional Papers in Archaeology 4. Uppsala: Societas Archaeologica Upsaliensis.

Kalman, Jonathan 2000a. Tandemägi stone grave - osteological report. Lang, Valter (ed.). Keskusest ääremaaks: Viljelusmajandusliku asustuse kujunemine ja areng Vihasoo-Palmse piirkonnas Virumaal = From centre to periphery: Establishment and history of farming settlement in Vihasoo and Palmse area (Virumaa, North Estonia). Appendix 5. Muinasaja Teadus $=$ Research into ancient times 7. Tallinn. [Teaduste Akadeemia Kirjastus], pp. $423-436$.

Kalman, Jonathan 2000b. Uusküla II skeletal analysis. Lang, Valter (ed.). Keskusest ääremaaks: Viljelusmajandusliku asustuse kujunemine ja areng Vihasoo-Palmse piirkonnas Virumaal = From centre to periphery: Establishment and history of farming settlement in Vihasoo and Palmse 
area (Virumaa, North Estonia). Appendix 5. Muinasaja Teadus $=$ Research into ancient times 7. Tallinn. [Teaduste Akadeemia Kirjastus], pp. 437442 .

Karvonen, Johannes 1998. Deliberately damaged objects in Iron Age cremation cemeteries: With reference to the objects from the cremation cemeteries of Ylipää in Lieto and Päivääniemi in Lempäälä. Fennoscandia Archaeologica XV, pp. 3-13.

Kochkurkina, Svetlana 1982. Drevniaia Korela. Leningrad: Nauka, Leningradskoe otd-nie.

Kustin, Aita 1958. Kalmistu XIII-XIV sajandist Karjas, Saaremaal.[13th-14th century cemetery in Karja, Saaremaa] ENSV Teaduste Akadeemia Toimetised: Ühiskonnateaduste seeria 7: 1, pp. 47-57.

Kustin, Aita 1966. Kiviringkalme Kureveres Saaremaal. Moora, Harri $\&$ Selirand, Jüri (eds.). Pronksiajast varase feodalismini. Uurimusi Baltimaade ja naaberalade arheoloogiast:[Pühendatud dr. M. Schmiedehelmile tema 70. sünnipäevaks] [From Bronze Age to Early Feudalism: Studies into archaeology of the Baltic area and the surroundings: ]Dedicated to Dr. M. Schmiedehelm on his 70th birthday]]. Tallinn: Eesti Raamat, pp. 8795.

Kõpp, Johan 1959. Kirik ja rahvas: Sugemeid eesti rahva vaimse palge kujunemise teelt [Church and People: On the formation of the spiritual worldview of the Estonians]. [Stockholm]: Eesti Vaimulik Raamat.

Lang, Valter \& Kalman, Jonatan 2000. Late Pre-Roman and Viking Age stone grave of Uusküla. Tamla, Ülle (ed.). Arheoloogilised välitööd Eestis 1999 = Archeological fieldwork in Estonia 1999. Tallinn: Muinsuskaitseamet, pp. 29-34.

Lang, Valter \& Ligi, Priit 1991. Muistsed kalmed ajaloolise demograafia allikana [Prehistoric burials as the source of historical demography]. Jaanits, Lembit \& Lang, Valter (eds.). Arheoloogiline kogumik. Muinasaja teadus $=$ Research into ancient times 1. Tallinn: Agu, pp. 216238.

Lehtosalo-Hilander, Pirkko-Liisa 1982. Luistari III: A Burial-Ground Reflecting The Finnish Viking Age Society. Suomen Muinaismuistoyhdistyksen Aikakauskirja = Finska Fornminnesföreningens Tidskrift 82: 3. Helsinki: Suomen Muinaismuistoyhdistys.

Huntington, Richard \& Metcalf, Peter 1991. Celebrations of Death: The Anthropology of Mortuary Ritual. 2nd ed. Cambridge [England] \& New York: Cambridge University Press.

Mägi, Marika \& Allmäe, Raili \& Maldre, Liina 1997. Viking Age graveyard at Piila, Saaremaa. Tamla, Ülle (ed.). Arheoloogilised välitööd Eestis 1997. Tallinn: Muinsuskaitseamet, pp. 99-116.

Mägi, Marika \& Rudi, Armin 1999. New stone circle graves at Piila cemetery, Saaremaa. Ed. Ülle Tamla. Arheoloogilised välitööd Eestis 1998 = Archeological fieldwork in Estonia 1998. Tallinn: Muinsuskaitseamet, pp. 39-49. 
Mägi, Marika 1999. Ühe ülikupere lugu: Tuulingumäe tarandkalme Tõnijal [A story of a noble family. Tuulingumäe tarand grave at Tõnija]. Pesti, Olavi (ed.). Saaremaa Muuseum: Kaheaastaraamat 1997-1998. Kuressaare: Saaremaa Muuseum, pp. 3-17.

Mägi, Marika 2002. At the Crossroads of Space and Time: Graves, Changing Society and Ideology on Saaremaa (Ösel), 9th-13th centuries AD. CCC [= Culture clash or compromise] papers 6. Reports (Gotland University College) [4?]. Tallinn: University of Tartu.

Mägi-Lõugas, Marika 1996. Archaeological excavations at Tõnija Tuulingumäe, Saaremaa. Tamla, Ülle (ed.). Teaduste Akadeemia Toimetised: Humanitaar- ja Sotsiaalteadused 45: 4, pp. 427-433.

Mägi-Lõugas, Marika 1997. Archaeological excavations at Tõnija Tuulingumäe tarand grave, Saaremaa. Tamla, Ülle (ed.). Arheoloogilised välitööd Eestis 1996. Stilus: Eesti Arheoloogiaseltsi teated 7. Tallinn: Eesti Arheoloogiaselts, pp. 29-39.

Markus, Kersti 2003. Vanimad kristlikud hauatähised Eestis [Earlier Christian Grave Marks in Estonia]. Mägi, Marika (ed.). Eesti aastal 1200: [Artiklikogumik]. Tallinn: Argo, pp. 107-124.

Pentikäinen, Juha 1990. Suomalaisen lähtö: Kirjoituksia pohjoisesta kuolemankulttuurista [Departure of a Finn: Writings about Nordic Death Culture]. Suomalaisen Kirjallisuuden Seuran Toimituksia 530. Helsinki: Suomalaisen Kirjallisuuden Seura.

Pesti, Olavi \& Rikas, Külli 1991. Saaremaa ajaloo- ja kultuurimälestised [Historical and cultural monuments of Saaremaa]. 2nd improved edition. Kaitstavad mälestised. Tallinn: Olion.

Purhonen, Paula 1998. Kristinuskon saapumisesta Suomeen: Uskontoarkeologinen tutkimus [On the Arrival of Christianity in Finland]. Suomen Muinaismuistoyhdistyksen Aikakauskirja 106. Helsinki: Suomen muinaismuistoyhdistys.

Selirand, Jüri 1962. Kaberla maa-alune kalmistu (13.-17. sajand) [The subterranean cemetery of Kaberla (13th-17th century)]. Moora Harri (ed.). Muistsed kalmed ja aarded. Arheoloogiline kogumik II. Tallinn: Eesti NSV Teaduste Akadeemia Ajaloo Instituut, pp. 131-168.

Sigvallius, Berit 1994. Funeral pyres: Iron Age cremations in North Spånga. Theses and papers in osteology 1. Stockholm: Osteological Research Laboratory, Stockholm University.

Sipelgas, Kaido 2000. Lääne- ja Saaremaa trapetsiaalsed hauaplaadid [Trapezoidal grave monuments in Lääne County and Saaremaa]. Paras, Ulla (ed.). Lä̈̈nemaa Muuseumi Toimetised = Proceedings of the Läänemaa Museum IV. Haapsalu: Läänemaa Muuseum, pp. 45-64.

Staecker, Jörn 1999. Rex regum et dominus dominorum: Die wikingerzeitlichen Kreutz- und Kruzifixanhänger als Ausdruck der Mission in Altdänemark und Schweden. Lund Studies in Medieval Archaeology 23. Lund: Almqvist \& Wiksell International. 
Staecker, Jörn 2001. In atrio ecclesiae. Die Bestattungssitte der dörflichen und städtischen Friedhöfe im Norden. Auns, Muntis (ed.). Lübeck Style? - Novgorod Style? Baltic Rim Central Places as Arenas for Cultural Encounters and Urbanisation 1100-1400 AD: Transactions of the central level: Symposium of the Culture Clash or Compromise (CCC) project held in Talsi, September 18-21, 1998. CCC (= Culture Clash or Compromise) papers 5. Riga: Nordik \& Visby: Centre for Baltic Studies, Gotland University College, pp. 187-258.

Tamla, Toomas 1991. Zur Datierung der Kirche von Viru-Nigula. Selirand, Jüri \& Tamla, Ülle (eds.). ENSV Teaduste Akadeemia Toimetised: Ühiskonnateaduste seeria 40: 4, pp. 376-377.

Tamla, Toomas 1992. Viru-Nigula kirik ja Maarja kabel [Viru-Nigula Church and Maarja chapel]. Stilus: Eesti Arheoloogiaseltsi teated $=$ Reports of the Estonian Archaelogical Society 4, pp. 18-36.

Thunmark-Nylén, Lena 1991. Vikingatid eller medeltid?: Om datering av gotländska gravfynd. Tor 23, pp. 141-202. 